\title{
Effects of Cyclosporin A on Rat Osteoblasts (ROS 17/2.8 Cells) In Vitro
}

\author{
Laurie K. McCauley, Thomas J. Rosol, and Charles C. Capen \\ Department of Veterinary Pathobiology, The Ohio State University, Columbus, Ohio, USA; and Department of Periodontics, Preventive \\ Dentistry and Geriatrics, School of Dentistry, University of Michigan, 1011 N. University Ave., Ann Arbor, Michigan 48109-1078, USA
}

Received January 17,1992, and in revised form March 2, 1992

Summary. The effects of the immunosuppressive drug cyclosporin A (CsA) were evaluated on ROS 17/2.8 cells in vitro. ROS cells were treated with CsA $(0,0.5,1.0,5.0 \mu \mathrm{g}$ / $\mathrm{ml}$ ) for 3 days with and without bovine parathyroid hormone (bPTH) (1-34) $10 \mathrm{nM}$. CsA at 0.5, 1.0, 5.0 $\mathrm{g} / \mathrm{ml}$ without PTH and at $5.0 \mu \mathrm{g} / \mathrm{ml}$ in the presence of PTH significantly inhibited proliferation, as determined by a tetrazolium colorimetric assay. In addition, ROS cell number was significantly reduced at 3 and 4 days with $\operatorname{CsA}(5.0 \mu \mathrm{g} / \mathrm{ml})$ without affecting cell viability. Incorporation of $\left[{ }^{3} \mathrm{H}\right]$-thymidine into DNA was significantly reduced by 3.0 and $5.0 \mu \mathrm{g} / \mathrm{ml}$ CsA after 12 and 24 hours exposure. Basal and 1,25-dihydroxyvitamin $\mathrm{D}_{3}$-stimulated alkaline phosphatase levels in confluent ROS cells were reduced $(P<0.05)$ with CsA $(1.0$ and $3.0 \mu \mathrm{g} / \mathrm{ml})$. Pretreatment of ROS $17 / 2.8$ cells with $\mathrm{CsA}$ did not alter PTH-stimulated cAMP levels or $\left[{ }^{125} \mathrm{I}\right]-\mathrm{PTH}$ TH binding to ROS cells. CsA treatment of ROS 17/2.8 cells induced a spindle-shaped appearance with loss of attachment in confluent cultures. When ROS cells were cultured in CsAcontaining media, cellular attachment at 6 and 12 hours was reduced $(P<0.05)$ compared with untreated ROS cells. These findings indicate that CsA was capable of inhibiting proliferation, cell number, mitogenesis, alkaline phosphatase levels, and cell attachment of ROS cells without affecting PTH binding or cAMP levels. This direct effect of CsA on osteoblasts may be important in changes of bone remodeling observed in CsA-treated humans and animals.

Key words: Bone - Osteoblast - Cyclosporin A - Attachment - Proliferation - Alkaline phosphatase.

Cyclosporin A ( CsA) is a potent immunosuppressive agent used in the prevention of graft rejection [1]. Cyclosporin A has been reported to inhibit bone resorption in vitro stimulated by parathyroid hormone (PTH), interleukin-1, prostaglandin $\mathrm{E}_{2}$, and 1,25 dihydroxyvitamin $\mathrm{D}$ [2-5]. The immunosuppressive properties of cyclosporin $A$ have been implicated to be responsible for its effects on bone as nonimmunosuppressive analogs of cyclosporin do not inhibit in vitro bone-resorbing activity [6]. Furthermore, CsA has been reported to inhibit production of tumor necrosis factor- $\alpha$ and $\beta$, and interferon- $\tau$ [7] which may be partly responsible for its actions on bone. Recently, it was reported that Cs A administered in vivo has profound effects on bone remodeling including increased bone formation and both increased or decreased bone resorption $[8,9]$. Patients treated

Offprint requests to: $\mathrm{L}$. K. McCauley with cyclosporin $\mathrm{A}$ in association with renal transplantation or vascularized bone grafts had increased osteoblastic and decreased resorptive parameters $[10,11]$. These findings have stimulated interest in the cellular mechanisms of CsA on bone.

There have been numerous studies on the mechanism of action of CsA on T-lymphocytes as they are the traditional target cell for CsA $[12,13]$. CsA has also been reported to affect other cell types including endothelial cells, keratinocytes, and hepatocytes $[12,14,15]$. A recent study of CsA effects on osteoclasts in vitro reported evidence that CsA inhibition of in vitro bone resorption was due to direct inhibition of the formation of osteoclasts, predominantly by decreasing osteoclast precursor fusion [16]. Most boneresorbing agents have been found to bind to and alter osteoblast function and do not directly modify osteoclast function [17]; however, the characteristics of CsA action on osteoblasts are unknown. A better understanding of the mechanisms of CsA function on bone could provide valuable information regarding basic properties of bone remodeling, pharmacotherapeutic intervention in metabolic bone disease, and the consequences of immunosuppression in bone physiology. The purpose of this study was to investigate CsA effects on ROS 17/2.8 osteoblast-like cells in vitro by evaluating parameters of proliferation, hormone responses, alkaline phosphatase activity, and indices of cell attachment.

\section{Materials and Methods}

\section{Cell Culture and Maintenance}

ROS 17/2.8 cells [18] were maintained in Dulbecco's Modified Eagle Medium (DMEM)-F12 media containing $50 \mathrm{mg} /$ liter gentamicin sulfate supplemented with $5 \%$ fetal bovine serum. Cultures were kept at $37^{\circ} \mathrm{C}$ in a humidified $95 \%$ air $/ 5 \% \mathrm{CO}_{2}$ atmosphere, and were subcultured twice weekly. For all assays, CsA was initially dissolved in ethanol, then brought to desired concentration with culture media. The ethanol was never greater than $0.01 \%$ of the media concentration. Controls received media with an equivalent concentration of ethanol.

\section{Determination of Cell Proliferation}

Proliferation of ROS cells was evaluated by the colorimetric MTT (tetrazolium) assay. The MTT assay is dependent on the reduction of the tetrazolium salt MTT [3-(4,5-dimethylthazol-2-yl)-2,5diphenyl tetrazolium bromide] by the mitochondrial dehydrogenase of viable cells to form a blue formazan product [19]. ROS cells were seeded at a concentration of $50,000 / \mathrm{ml}$ in a volume of $0.2 \mathrm{ml}$ in 96-well plates (Costar, Cambridge, MA) and were treated for 4 days with varying concentrations of CsA with and without bPTH (1-34) 10 $\mathrm{nM}$ (Bachem Inc., Torrance, CA). Fresh media and treatments were 
added daily. At the end of the treatment intervals MTT (Sigma Chemicals Co., St. Louis, MO) $[5 \mathrm{mg} / \mathrm{ml}$ in phosphate buffered saline (PBS)] was added to all wells $(25 \mu \mathrm{l})$ and incubated at $37^{\circ} \mathrm{C}$ for 4 hours. After the MTT incubation, $100 \mu l$ lysing buffer (20\% SDS, $50 \%$ dimethyl formamide, $\mathrm{pH} 4.7$ ) was added to each well and incubated overnight at $37^{\circ} \mathrm{C}$. The resultant solution was read in a microplate reader at $580 \mathrm{~nm}$. The optical density reflects the number of living cells present in culture.

\section{CsA Effects on Cell Number and Viability}

ROS $17 / 2.8$ cells were plated in 24-well plates at an initial concentration of $50,000 / \mathrm{ml} /$ well. Cells were incubated overnight in media to allow cell attachment. Every 24 hours from $1-4$ days, the media was aspirated and CsA or control media was replaced in the wells. Beginning on day 1 , individual wells were trypsinized and cells were enumerated and viability evaluated via trypan blue dye exclusion.

\section{${ }^{3}[H]$-Thymidine Incorporation into DNA}

The incorporation of ${ }^{3}[\mathrm{H}]$-thymidine into trichloroacetic acid (TCA)precipitable material was measured on confluent ROS 17/2.8 cells treated in triplicate with CsA or control media for 24 hours (unless otherwise indicated). During the final 4 hours, ${ }^{3}[\mathrm{H}]$-thymidine (ICN Biomedicals, Inc., Costa Mesa, CA) was added to a final concentration of $1.0 \mu \mathrm{Ci} / \mathrm{ml}$. At the end of the incubations each well was rinsed twice with $0.5 \mathrm{ml}$ ice-cold Hanks buffered salt solution (HBSS) and twice with $0.5 \mathrm{ml}$ ice-cold $10 \%$ TCA. The monolayer was lysed with $0.5 \mathrm{M} \mathrm{NaOH}$, and the resultant suspension was counted in a beta scintillation counter.

\section{Measurement of Alkaline Phosphatase Activity}

Measurement of alkaline phosphatase activity was performed as described by Wrana et al. [20]. Briefly, confluent ROS 17/2.8 cells were treated with $\mathrm{CsA}$ and/or 1,25-dihydroxyvitamin $\mathrm{D}_{3}$ $\left(1,25(\mathrm{OH})_{2} \mathrm{D}_{3}\right)$, for 24 hours (unless otherwise indicated), rinsed twice with ice-cold HBSS, and scraped into $0.5 \mathrm{ml} 50 \mathrm{mM}$ Tris $/ \mathrm{HCl}$ buffer, $\mathrm{pH} 7.4$, and the dishes were rinsed with $1.0 \mathrm{ml}$ Tris buffer. The cell suspension was sonicated on ice with a Branson Sonifier (Danbury, CT) and centrifuged for 5 minutes at $10,000 \mathrm{~g}$. Ten microliters of the supernatant was mixed with $200 \mu$ l of substrate [7.5

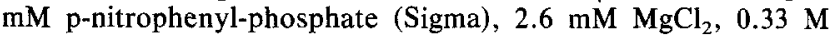
2-amino-2-methyl-1-propanol, $\mathrm{pH} 10.3$ ] in individual wells of a 96well tissue culture plate. The plate was then incubated for $45 \mathrm{~min}$ utes at $37^{\circ} \mathrm{C}$, and the reaction was stopped with the addition of $90 \mu \mathrm{l}$ $0.5 \mathrm{~N} \mathrm{NaOH}$. The plate was read on a microplate reader at $410 \mathrm{~nm}$, and compared against a standard curve obtained with p-nitrophenol (Sigma).

Protein concentrations were determined using a Micro BCA Protein Assay (Pierce, Rockford, IL).

\section{Measurement of Adenylate Cyclase Stimulation}

The adenylate cyclase stimulation assay and cAMP binding assay were performed as previously described [21] with the following modifications. ROS $17 / 2.8$ cells were grown $24-48$ hours postconfluence in 24-well plates. CsA was incubated with confluent ROS cells in triplicate for 8-48 hours prior to a 10 -minute incubation with bPTH (1-34) 0-10 nM at $37^{\circ} \mathrm{C}$ in calcium- and magnesium-free HBSS containing $0.1 \%$ bovine serum albumin (BSA) (Sigma) and $1 \mathrm{mM}$ isobutylmethylxanthine (IBMX) (Sigma). The media was aspirated and $250 \mu \mathrm{l}$ ice-cold $5 \%$ perchloric acid was added to each well. The plates were incubated at $-20^{\circ} \mathrm{C}$ overnight to extract the cAMP. After thawing, the extract was transferred to tubes, the $\mathrm{pH}$ was adjusted to 7.5 with $4 \mathrm{~N} \mathrm{KOH}$, and the extract was centrifuged to remove the precipitate. The neutralized extract was then assayed for cAMP content using a cAMP binding protein assay.

The cAMP binding protein assay was performed as follows. To each tube was added assay buffer (50 $\mathrm{mM}$ Tris, $5 \mathrm{mM}$ EDTA, $\mathrm{pH}$ 7.4), $100 \mu \mathrm{l}$ standards or unknowns, $\left.{ }^{3} \mathrm{H}\right]$ cAMP $(10,000 \mathrm{cpm} /$ tube $)$, and cAMP binding protein sufficient to bind $40-60 \%$ of the added radioactivity in a final volume of $250 \mu$. The tubes were incubated for 90 minutes on ice. Dextran-coated charcoal $(0.5 \mathrm{mg} / \mathrm{ml}$ dextran and $5.0 \mathrm{mg} / \mathrm{ml}$ charcoal) was added to each tube $(600 \mu \mathrm{l})$, incubated an additional 30 minutes on ice, then centrifuged to remove the unbound from the bound cAMP-binding protein- $\left[{ }^{3} \mathrm{H}\right]-\mathrm{cAMP}$ complexes. The supernatant was decanted directly into scintillation vials and counted in a liquid scintillation spectrophotometer. Samples were run in duplicate, and concentration of cAMP was calculated by the log-logit method using the Securia 1.0, Packard (Indianapolis, IN) computer program. Data were expressed as pmol cAMP/well.

\section{PTH Receptor Binding Assays}

[Tyr $\left.{ }^{36}\right]-P T H r P$ (1-36) (Bachem) was iodinated using Iodo Beads (Pierce, Rockford, IL) and purified by high performance liquid chromatography (HPLC) as previously described [21]. Briefly, $1 \mathrm{mCi}$ [ $\left.{ }^{125} \mathrm{I}\right] \mathrm{Na}$ (ICN Biomedicals) was added to one Iodobead and incubated at room temperature for 5 minutes prior to the addition of 10 $\mu \mathrm{g}\left[\mathrm{Tyr}^{36}\right]$-PTHrP (1-36) in $0.5 \mathrm{M}$ sodium phosphate buffer ( $\mathrm{pH} 7.5$ ). After incubating the reaction mixture for 15 minutes at room temperature, the sample was injected into a Waters 600 HPLC system (Milford, MA) and separated on a VYDAC $\mathrm{C}_{4}$ reverse phase column (The Separations Group, Hesperia, CA).

ROS $17 / 2.8$ cells 24 hours postconfluence were incubated with CsA $3 \mu \mathrm{g} / \mathrm{ml}$ in DMEM-F12 $5 \%$ FBS for 5 hours at $37^{\circ} \mathrm{C}$ prior to receptor binding studies. After incubation, the media was removed and replaced with fresh media. To each well $50,000 \mathrm{cpm}$ of monoiodinated $\left[\mathrm{Tyr}^{36}\right]$-PTHrP (1-36) was added in addition to varying concentrations of bPTH (1-34) (Bachem Inc.). The cells were incubated for 2 hours at $4^{\circ} \mathrm{C}$ on a rocker platform. The unbound peptides were washed off the cell monolayer twice with HBSS, the cells were lysed with $0.5 \mathrm{M} \mathrm{NaOH}$ for 30 minutes, and the resultant suspension was counted in a gamma counter. Specific binding was calculated by subtracting the radioactivity bound in the presence of excess bPTH $(1-34)(1.0 \mu \mathrm{M})$ from that observed in the presence of tracer only. Data are expressed as a percentage of maximal specific binding for each concentration of added bPTH.

\section{Cell Attachment Assay}

Confluent ROS 17/2.8 cells were trypsinized and suspended in control media or media containing $\mathrm{CsA}(1 \mu \mathrm{g} / \mathrm{ml}$ final concentration) at a concentration of $100,000 \mathrm{cells} / \mathrm{ml}$. One milliliter samples of each cell suspension were plated in a 24-well plate and allowed to attach to the plate surface for $1,3,6$, and 12 hours. At the designated time points, each well was washed gently with HBSS twice and the remaining attached cells were removed by trypsinization. Two samples of the trypsinized cell suspension from each of three wells per treatment group were enumerated via trypan blue dye exclusion. The number of cells attached to the well was expressed as a percentage of the total number of cells originally seeded in the well.

\section{Statistical Analyses}

Data for the proliferation and viable cell number assays were evaluated by analysis of variance followed by multiple comparisons using a corrected Bonferroni $P$ value. Data for all other assays were evaluated using Student's $t$ test. The statistics were performed using Instat 1.1 and a MS/DOS computer.

\section{Results}

\section{CsA Effects on Cell Proliferation}

CsA $(0.5,1.0$, and $5.0 \mu \mathrm{g} / \mathrm{ml})$ significantly inhibited ROS cell proliferation after 3 days of treatment (Fig. 1). When bPTH 


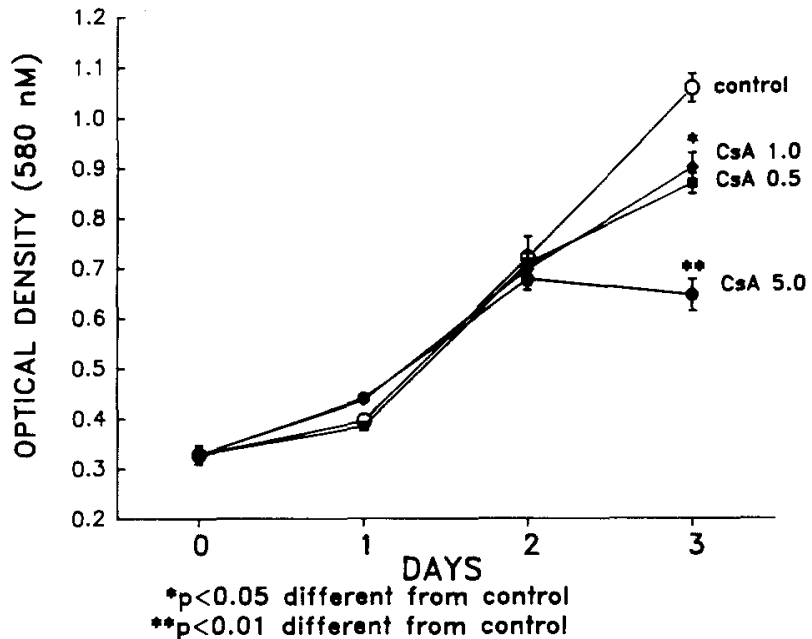

Fig. 1. Effect of cyclosporin A (CsA) on ROS $17 / 2.8$ cell proliferation. Optical density values of lysed cell suspensions from the MTT colorimetric tetrazolium reduction assay are reported for triplicate samples (mean \pm SEM).

(1-34) (10 nM) was incubated with the ROS cells in addition to CsA, a similar pattern of inhibition was seen; however, only the CsA $5.0 \mu \mathrm{g} / \mathrm{ml}$ group was significantly different than control (Fig. 2). This may indicate that PTH was effective in partial but not total prevention of the inhibition of proliferation due to CsA.

\section{CsA Effects on Cell Number and Viability}

Trypan blue dye exclusion enumeration of ROS cells treated with CsA was performed to further confirm the effects of CsA on cell proliferation and to determine if CsA affected cell viability. The results of CsA treatment over a 4-day period are illustrated in Figure 3. Viability of ROS cells was greater than $90 \%$ for all groups. CsA significantly reduced cell numbers compared with control only at a concentration of $5.0 \mu \mathrm{g} / \mathrm{ml}$ on both days 3 and 4 of treatment.

\section{${ }^{3}[H]$-Thymidine Incorporation into DNA}

The ability of CsA to modify mitogenesis was determined by ${ }^{3}[\mathrm{H}]$-thymidine incorporation into DNA. CsA significantly inhibited thymidine incorporation at 3.0 and $5.0 \mu \mathrm{g} / \mathrm{ml}$ after a 24-hour treatment period (Fig. 4). When an evaluation of mitogenesis was performed with CsA $(3 \mu \mathrm{g} / \mathrm{ml})$ treatment for 4-24 hours, a significant reduction in thymidine incorporation was seen as early as 12 hours (Fig. 5).

\section{CsA Effects on Alkaline Phosphatase Activity}

ROS cell alkaline phosphatase activity was significantly reduced after 24-hour treatment with CsA $(1.0$ and $3.0 \mu \mathrm{g} / \mathrm{ml})$ compared with control (Fig. 6). The reduction in alkaline phosphatase levels was significant at 24 hours, but not 4 and 8 hours (Fig. 7). In addition, CsA treatment was capable of reversing the stimulatory effects of $1,25(\mathrm{OH})_{2} \mathrm{D}_{3}$ on alkaline phosphatase activity in confluent ROS cells (Fig. 8).

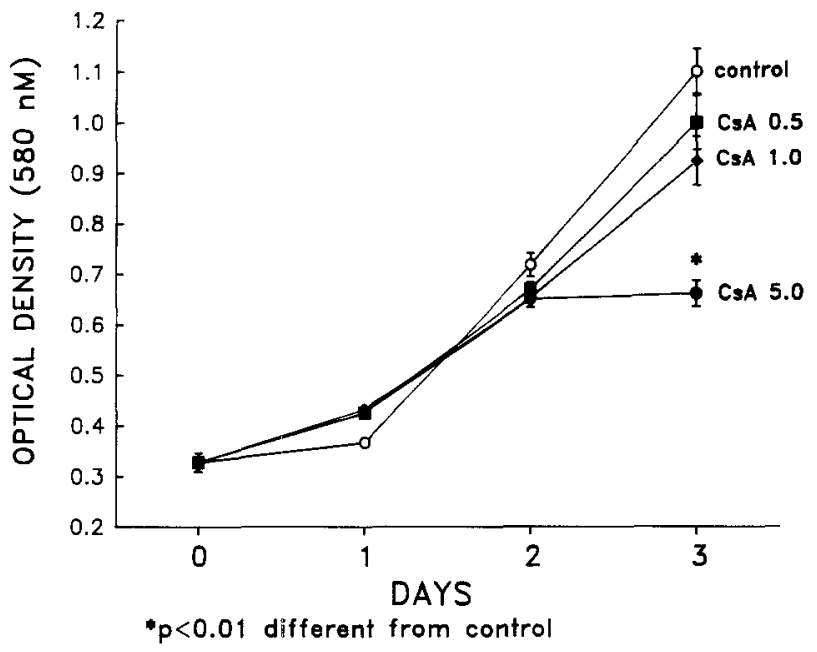

Fig. 2. Effects of cyclosporin A (CsA) in the presence of bPTH (1-34) $(10 \mathrm{nM})$ on ROS $17 / 2.8$ cell proliferation. Optical density values of lysed cell suspensions from the MTT colorimetric tetrazolium reduction assay are reported for triplicate samples (mean \pm SEM).

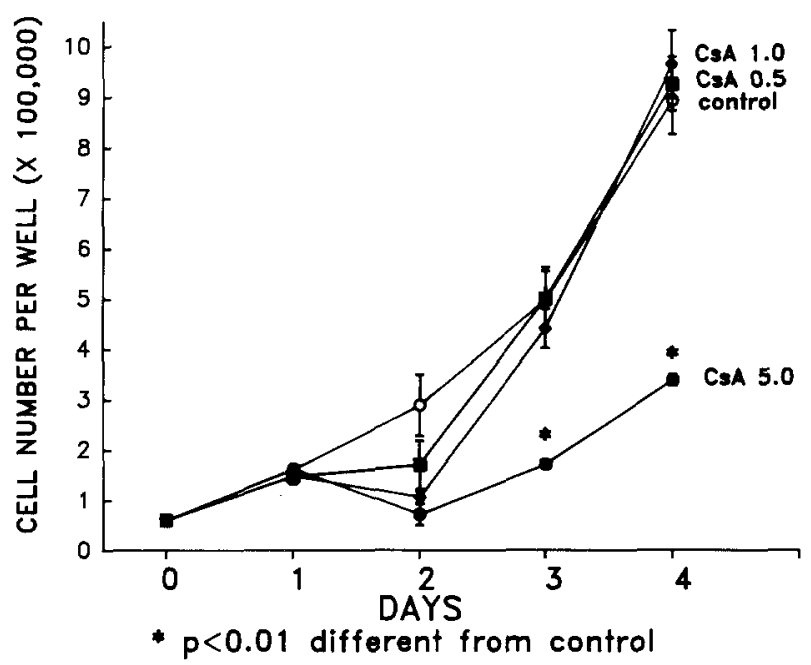

Fig. 3. Effects of cyclosporin A (CsA) on ROS 17/2.8 cell number. Cell enumeration was performed on triplicate samples by the trypan blue dye exclusion method (mean \pm SEM).

\section{CsA Effects on Adenylate Cyclase Activity}

The ability of CsA to alter PTH-stimulated adenylate cyclase activity was evaluated in confluent ROS cells. Bovine PTH (1-34) (10 $\mathrm{nM})$ increased cAMP levels greater than tenfold; however, pretreatment for 24-48 hours with CsA $(0-5.0 \mu \mathrm{g} /$ $\mathrm{ml})$ did not alter baseline or PTH-induced adenylate cyclase activity (data for CsA $3.0 \mu \mathrm{g} / \mathrm{ml}$ for 48 hours shown in Fig. 9; other data not shown).

\section{CsA Effects on PTHrP Binding to PTH Receptors on ROS Cells}

As bPTH and PTHrP have been found to bind with equal affinity to receptors on osteoblasts [22], bP'TH (1-34) was used to evaluate the ability of CsA-treatment to alter PTH/ PTHrP receptors on ROS $17 / 2.8$ cells. The addition of bPTH 


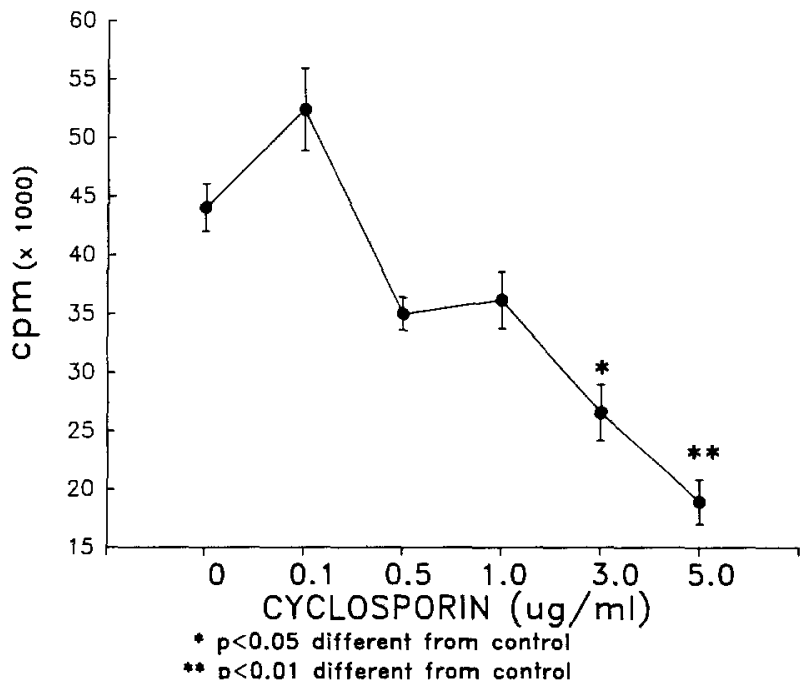

Fig. 4. Effects of cyclosporin A (CsA) on ROS 17/2.8 cell mitogenesis. Incorporation of $\left[{ }^{3} \mathrm{H}\right]$-thymidine into DNA in triplicate samples is expressed as counts per minute $(\mathrm{cpm})$ (mean \pm SEM).

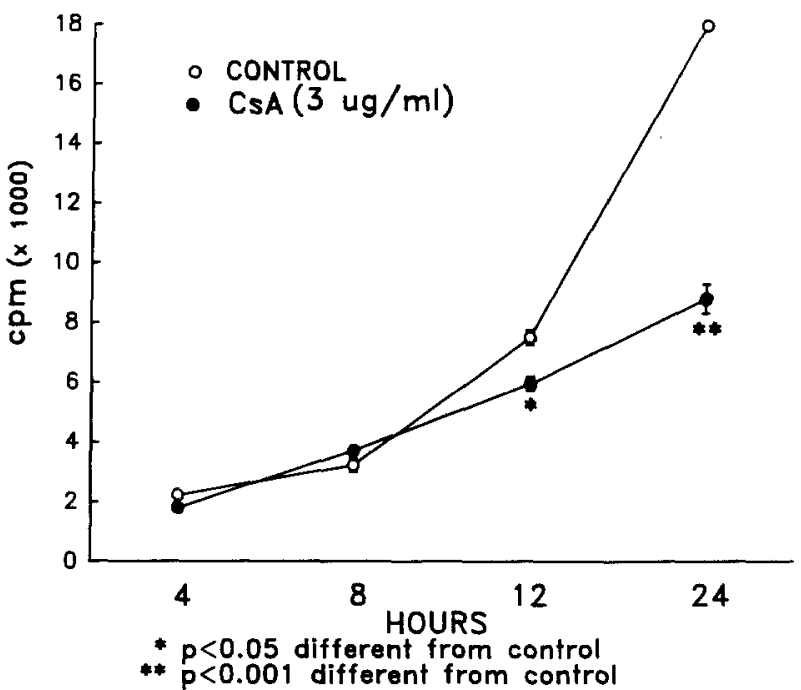

Fig. 5. Effects of cyclosporin A (CsA) on ROS 17/2.8 cell mitogenesis. Incorporation of $\left[{ }^{3} \mathrm{H}\right]$-thymidine into DNA in triplicate samples is expressed as cpm (mean \pm SEM).

(1-34) during incubation of iodinated PTHrP (1-36) to ROS cells previously incubated in CsA or control media was capable of reducing binding of iodinated PTHrP (1-36) (Fig. 10). This indicated that PTHrP was an effective ligand to the PTH receptors on ROS cells; however, as there was no difference in percentage of maximal specific binding between control or CsA-treated cells, the CsA did not modify the PTH-receptor binding.

\section{CsA Effects on ROS 17/2.8 Cell Morphology}

Morphologic changes were apparent in ROS 17/2.8 cells after a 48 -hour exposure to CsA $(3 \mu \mathrm{g} / \mathrm{ml})$ prior to confluence (Fig. 11). Preconfluent (Fig. 11a) and confluent (Fig. 11c) control cells demonstrate normal osteoblastic cell morphol-
L. K. McCauley et al.: Effects of Cyclosporin A on Osteoblasts

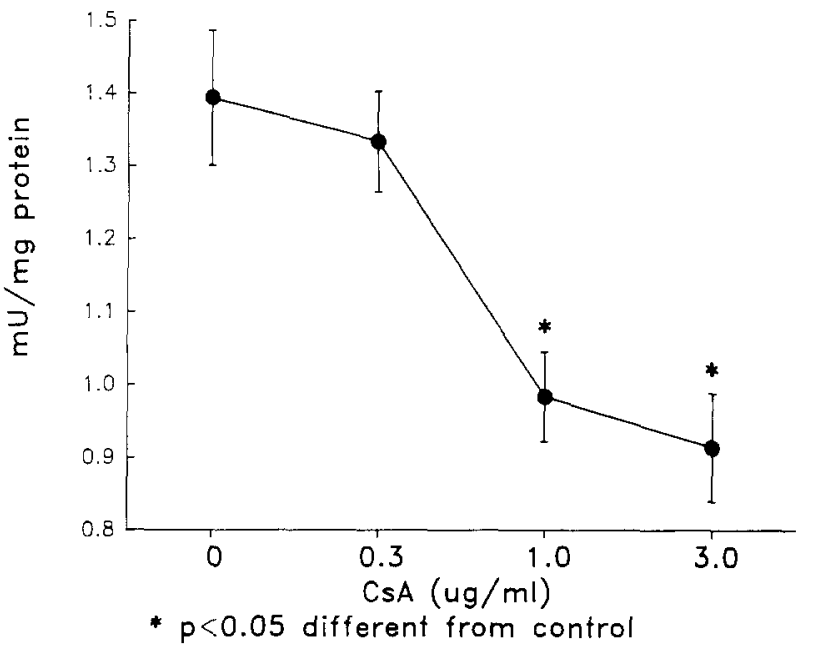

Fig. 6. Effects of cyclosporin A (CsA) $(0-3.0 \mathrm{mg} / \mathrm{ml} ; 24$ hours) on ROS 17/2.8 cell alkaline phosphatase levels. Alkaline phosphatase activity is expressed as $\mathrm{mU} / \mathrm{mg}$ protein in triplicate samples (mean $\pm \mathrm{SEM}$ ).

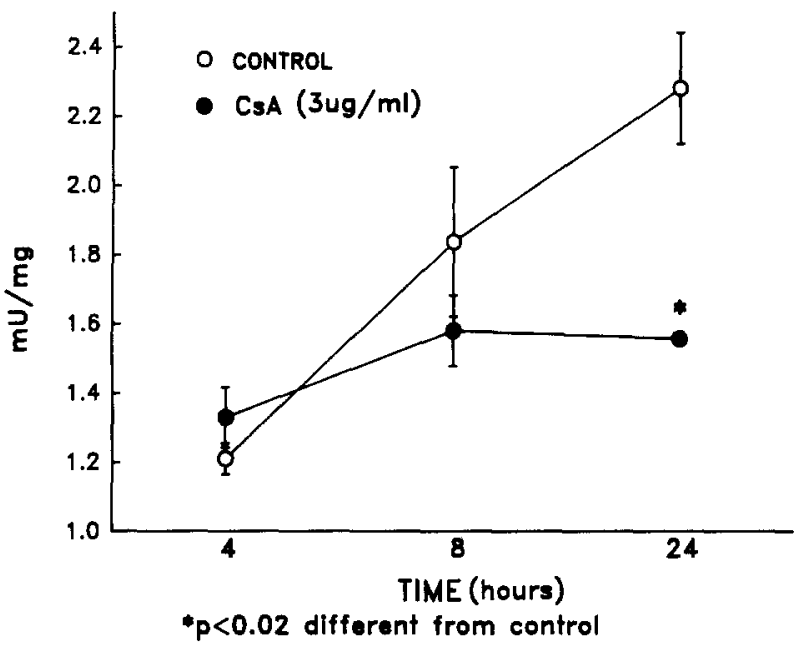

Fig. 7. Effects of cyclosporin A (CsA) (3 mg/ml; 4-24 hours) on ROS $17 / 2.8$ cell alkaline phosphatase levels. Alkaline phosphatase activity is expressed as $\mathrm{mU} / \mathrm{mg}$ protein in triplicate samples (mean \pm SEM).

ogy and cell-to-cell interaction. The CsA-treated ROS cells became more spindle-shaped with a relative loss of uniform cell-cell contact (Fig. 11b). When ROS cells were treated with CsA ( $3 \mu \mathrm{g} / \mathrm{ml})$ after confluence for 24 hours, the spindle shape was induced with frequent rounding up of cells (Fig. 11d). When fresh media without CsA was placed on confluent CsA-treated cells, a reversal of effects was complete within 48 hours (not shown).

\section{CsA Effects on ROS Cell Attachment}

The ability of ROS cells to attach to 24-well culture plates is shown in Figure 12. The percentage of attached ROS cells increased with time for both control and CsA $(1 \mu \mathrm{g} / \mathrm{ml})-$ treated cells; however, CsA-treated cells did not attach as rapidly which resulted in significantly lower numbers of cells attached at 6 and 12 hours after plating. 


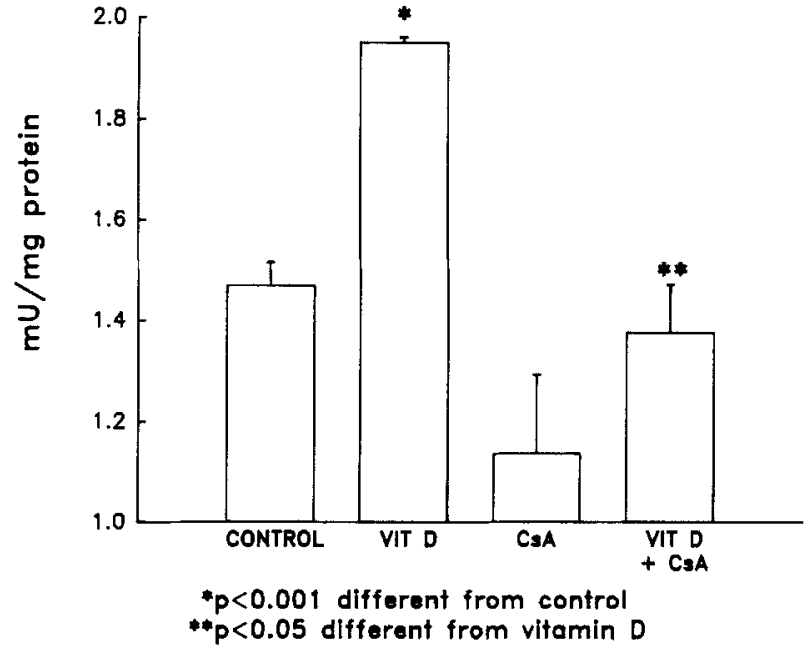

Fig. 8. Effects of 24-hour treatment of cyclosporin A (CsA) $(3 \mu \mathrm{g} /$ $\mathrm{ml}$ ) and $1,25(\mathrm{OH})_{2} \mathrm{D}_{3}$ (Vit D) $(10 \mathrm{nM})$ on levels of alkaline phosphatase in ROS $17 / 2.8$ cells. Alkaline phosphatase activity is expressed as $\mathrm{mU} / \mathrm{mg}$ protein in triplicate samples (mean \pm SEM).

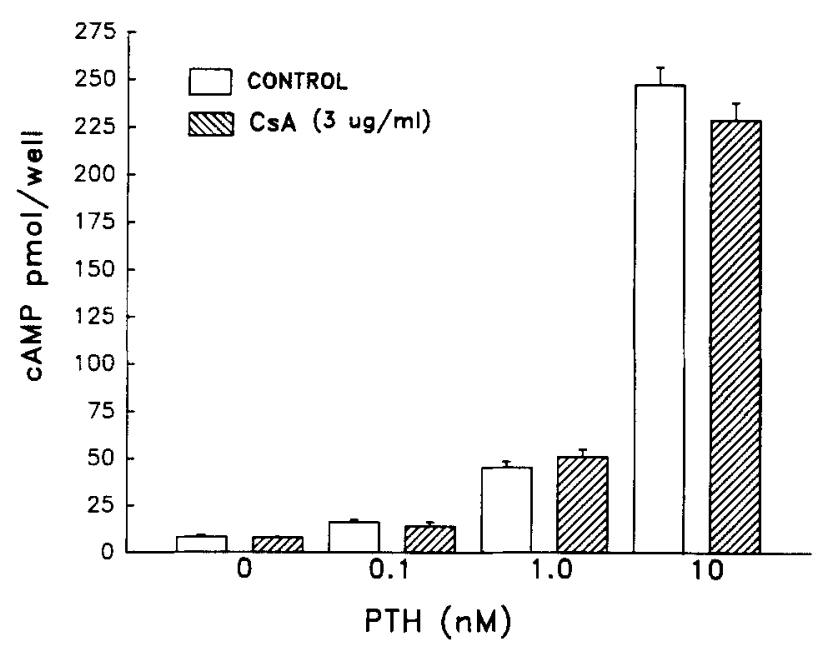

Fig. 9. Effects of 48-hour pretreatment with cyclosporin $A$ (CsA) (3 $\mu \mathrm{g} / \mathrm{ml}$ ) on PTH-stimulated (10-minute exposure) cAMP levels in ROS 17/2.8 cells. Levels of CAMP in triplicate samples are shown (mean \pm SEM). There was no significant difference between CsAtreated and control samples for concentrations of PTH $(0-10 \mathrm{nM})$.

\section{Discussion}

Profound changes on ROS $17 / 2.8$ cellular activity and morphology were observed with cyclosporin $A$ treatment. The dosages of CsA selected were similar to those used for in vitro studies of CsA effects on bone resorption and osteoclast function $[2,16,23]$ and approach the range of blood values found in patients administered CsA [24]. CsA was capable of inhibiting proliferation at doses as low as $0.5 \mu \mathrm{g}$ / $\mathrm{ml}$ based on the MTT tetrazolium reduction assay. Enumeration by trypan blue exclusion was performed to insure that the CsA was not toxic to the cells. Cell viability was greater than $90 \%$ for all treatment groups, eliminating the likelihood of cell toxicity. In addition, the morphologic changes induced by CsA, including a spindloid appearance and detachment from culture dishes, was effectively reversed within 48

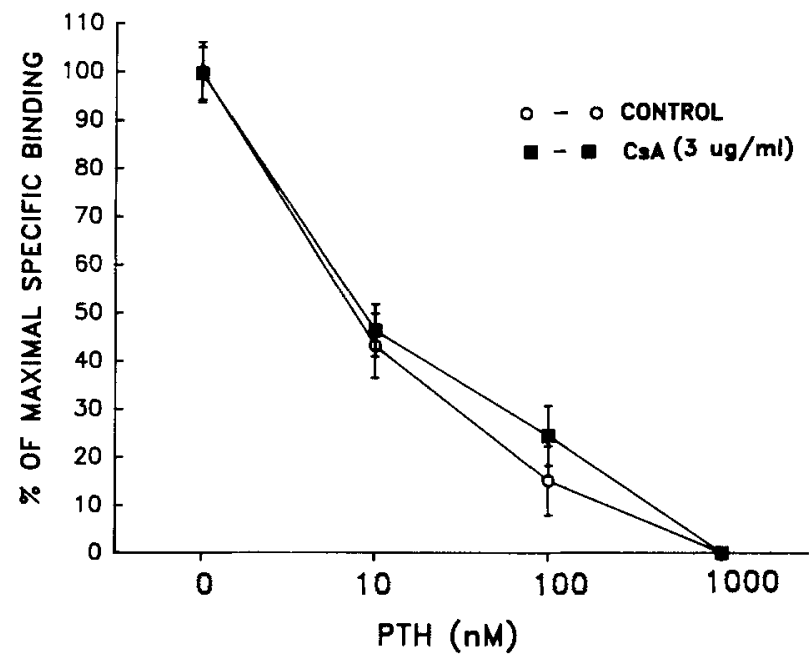

Fig. 10. Effects of cyclosporin A (CsA) on iodinated PTHrP binding to ROS $17 / 2.8$ cells. Binding of iodinated $\mathrm{PTHrP}$ after preincubation of ROS cells with CsA ( $3 \mu \mathrm{g} / \mathrm{ml}$ for 5 hours) is expressed a percentage of maximal specific binding (total binding minus binding in the presence of unlabeled $1 \mu \mathrm{M}$ PTH) (mean \pm SEM). There was no significant difference between cells pretreated with CsA and control cells.

hours when cyclosporin A administration was discontinued. The tetrazolium assay was a more sensitive reflection of differences in cell proliferation than the trypan blue dye exclusion method. A similar reduction in cell numbers has been reported for CsA treatment in mitogen-induced proliferation of normal human keratinocytes and umbilical endothelial cells [14]. In our study there was an inhibition of $\left[{ }^{3} \mathrm{H}\right]-$ thymidine incorporation into DNA in ROS cells treated with CsA as early as 12 hours. This also has been reported for other cell types including lymphocytes, thymocytes, and osteoclasts $[16,25,26]$.

CsA was effective in reducing alkaline phosphatase levels in confluent ROS cell cultures. Alkaline phosphatase is considered to be a characteristic marker for the osteoblast phenotype [27], and levels are elevated in mature ROS 17/2.8 cells with $10^{-8} \mathrm{M} 1,25(\mathrm{OH})_{2} \mathrm{D}_{3}$ [28]. CsA was effective in reducing both basal levels and $1,25(\mathrm{OH})_{2} \mathrm{D}_{3}$-stimulated levels of alkaline phosphatase. CsA has been reported to reduce $1,25(\mathrm{OH})_{2} \mathrm{D}_{3}$-stimulated osteocalcin levels in primary bone cell populations [29]. These findings, in addition to the CsA alteration of normal osteoblast morphology, reflect a suppression of osteoblastic features. In addition, the findings that $\mathrm{CsA}$ reduced cell attachment suggests the CsA-treated ROS cells may have reduced expression of proteins such as fibronectin and osteopontin, which are important for cellmatrix interactions $[30,31]$.

The ability of CsA to alter PTH responses was minimal. Although in the presence of PTH, higher concentrations of CsA were required to achieve significant inhibition of proliferation compared with controls, the differences between CsA treatment with and without PTH were not significant. Preincubation with CsA did not alter cAMP production stimulation by PTH, and PTHrP binding was not different when ROS cells were treated with CsA. The findings that CsA did not affect PTH binding are in contrast with a recent study by Chowdhury et al. [5] who report CsA treatment markedly reduced PTH binding to osteoblast-like cells. Several differences exist between their methods and ours which may account for the differing results. Their studies were performed 

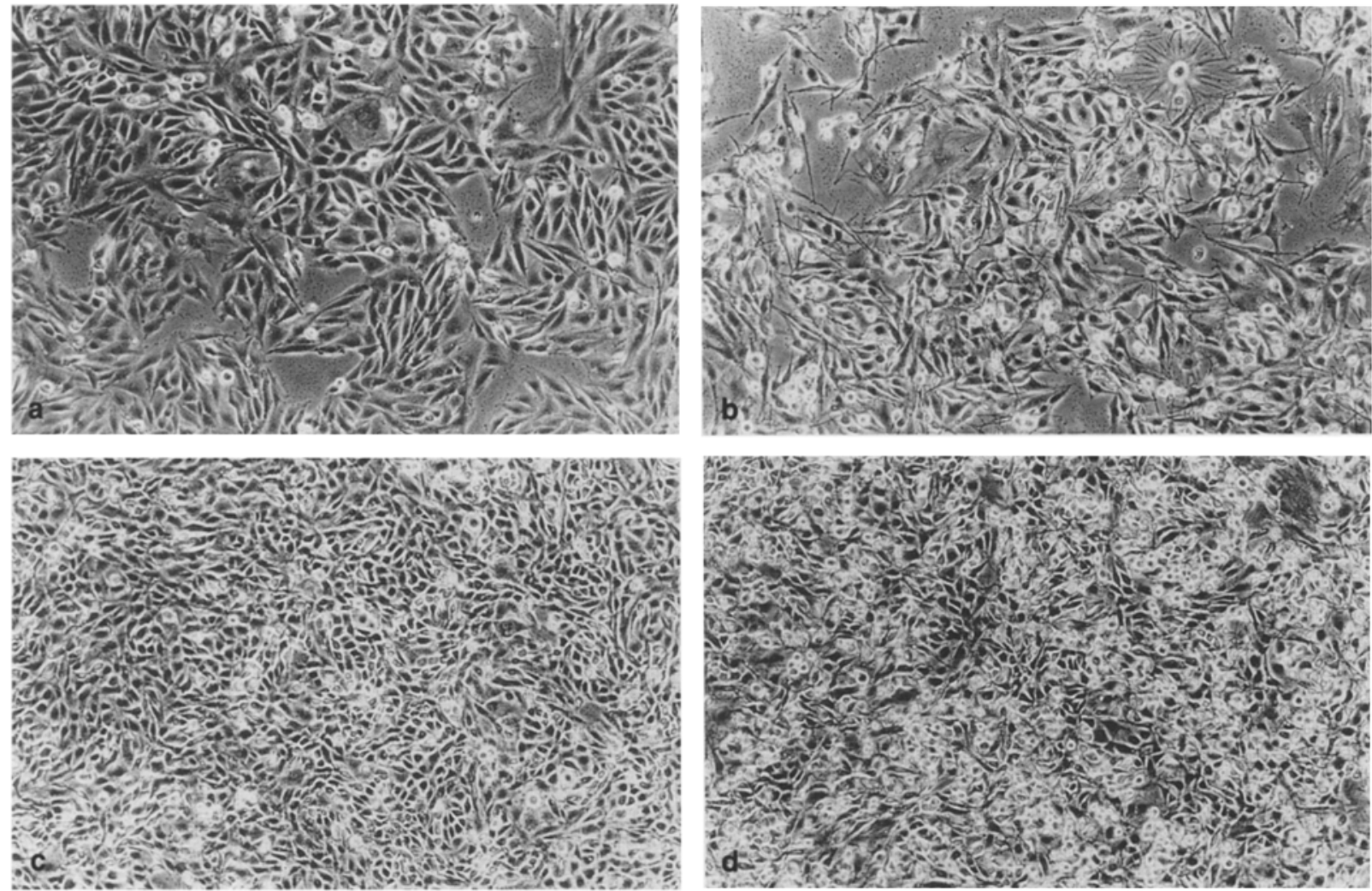

Fig. 11. Phase contrast micrographs of ROS 17/2.8 cells. Preconfluent (A) and confluent (C) control cells have normal osteoblastic characteristics whereas preconfluent (B) and confluent (D) cells treated with cyclosporin A ( $3 \mu \mathrm{g} / \mathrm{ml}$ for 48 and 24 hours, respectively) have a spindle shape with many rounded, detached cells, and a loss of uniform cell-cell contact.

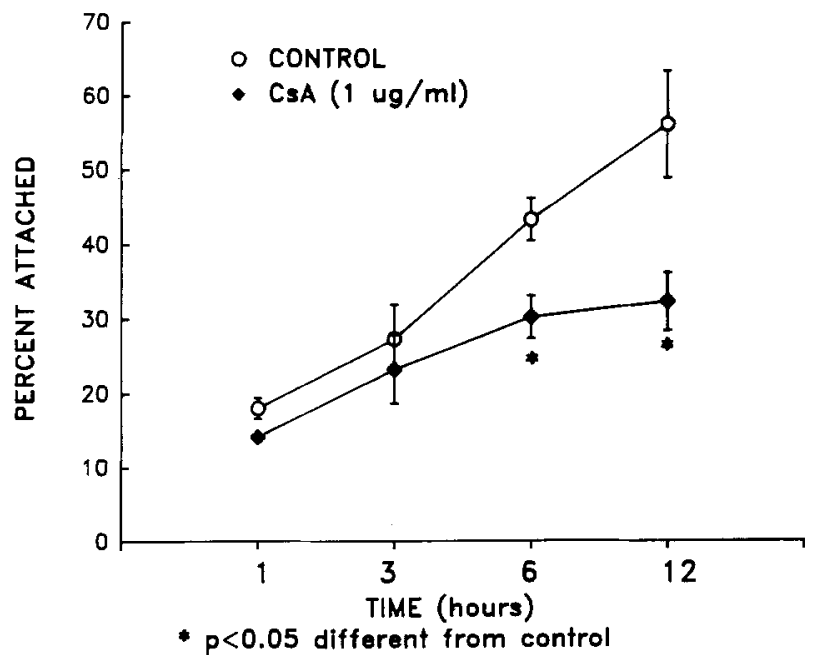

Fig. 12. Effects of cyclosporin A (CsA) on cell attachment. The percentage of cells plated to culture dishes that remained attached after the designated time periods is reported for triplicate samples (mean \pm SEM).

with cells in suspension using a different osteoblast-like cell line (Saos-2) as opposed to the attached cell receptor assay we performed. For any of the CsA-mediated cellular effects reported in this study, differences were not apparent earlier than 5 hours after CsA incubation.
The significance of these findings in relation to CsA effects on the inhibition of in vitro bone resorption and stimulation of bone formation in vivo remain to be elucidated. As the osteoblast is responsible for secreting bone matrix components that are chemotactic for osteoclasts (e.g., osteocalcin, collagen peptides) [32], in addition to putative factor(s) directly capable of activating osteoclasts [33], it is possible that CsA alters the ability of osteoblasts to secrete these factors, resulting in a decline of osteoclast recruitment and stimulation. The significance of these findings in regard to bone formation are unclear as bone formation is increased with CsA administration in vivo [34]. It is likely that the in vivo effects on the osteoblast are the result of a complex interaction of both the primary effects mediated by CsA and also secondary effects that occur as a result of altered bone remodeling. These will be important avenues of investigation leading to a better understanding of CsA-mediated osteoblast and osteoclast function.

In summary, CsA was capable of (1) inhibiting proliferation and mitogenesis without compromising cell viability, (2) reducing ROS cell alkaline phosphatase levels, and (3) inhibiting ROS cell attachment without having significant effects on PTH-stimulated cAMP levels or PTHrP binding to ROS cell receptors. These findings suggest that CsA has a direct effect on osteoblast-like cells, indicating that CsA effects on bone remodeling may be partly due to osteoblastic modulation.

Acknowledgments. This work was supported by NIH Grant DE05524 and the American Fund for Dental Health. 


\section{References}

1. Foxwell BMJ, Ruffel B (1989) The mechanisms of action of cyclosporine. Immunol Allergy Clin North Am 9:79-93

2. Stewart PJ, Green OC, Stern PH (1986) Cyclosporine A inhibits calcemic hormone-induced bone resorption in vitro. $J$ Bone Miner Res 1:285-291

3. Klaushofer K, Hoffman O, Stewart PJ, Czerwenka E, Koller K, Peterlik M, Stern PH (1987) Cyclosporine A inhibits bone resorption in cultured neonatal mouse calvaria. J Pharmacol Exp Ther 243:584-590

4. McCauley LK, Rosol TJ, Stromberg PC, Capen CC (1991) Effects of interleukin-1 alpha and cyclosporin $\mathrm{A}$ in vivo and in vitro on bone and lymphoid tissues in mice. Toxicol Pathol 19:1-10

5. Chowdhury MH, Shen V, Dempster DW (1991) Effects of cyclosporine A on chick osteoclasts in vitro. Calcif Tissue Int 49:275-279

6. Stewart PJ, Stern PH (1989) Cyclosporines: correlation of immunosuppressive activity and inhibition of bone resorption. Calcif Tissue Int 45:222-226

7. Espevik T, Figari IS, Shalaby MR, Lackides GA, Lewis GD, Shepard HM, Palladino MA (1987) Inhibition of cytokine production by cyclosporin $\mathrm{A}$ and transforming growth factor beta. J Exp Med 166:571-576

8. Movsowitz C, Epstein S, Ismail F, Fallon M, Thomas S (1989) Cyclosporin A in the oophorectimized rat: unexpected severe bone resorption. J Bone Miner Res 4:393-398

9. Orcel P, Bielakoff J, Modrowski D, Miravet L, DeVernejoul MC (1989) Cyclosporin A induces in vivo inhibition of resorption and stimulation of formation in rat bone. $J$ Bone Miner Res $4: 387-391$

10. Wilmink JM, Bras J, Surachno S, vHeyst JLAM, vdHorst JM (1989) Bone repair in cyclosporin-treated renal transplant patients. Transplant Proc 21:1492-1494

11. Li XQ, Stevenson S, Klein L, Davy DT, Shaffer JW, Goldberg VM (1991) Differential patterns of incorporation and remodeling among various types of bone grafts. Acta Anat 140:236-244

12. Drugge RJ, Handschumacher RE (1988) Cyclosporinemechanism of action. Transplant Proc 20:301-309

13. Jenkins MK, Schwartz RH, Pardoll DM (1988) Effects of cyclosporine A on $\mathrm{T}$ cell development and clonal deletion. Science 241:1655-1658

14. Sharpe RJ, Arndt KA, Bauer SI, Maione TE (1989) Cyclosporine inhibits basic fibroblast growth factor-driven proliferation of human endothelial cells and keratinocytes. Arch Dermatol 125: 1359-1362

15. Nicchitta CV, Kamoun M, Williamson JR (1985) Cyclosporine augments receptor-mediated cellular $\mathrm{Ca}^{2+}$ fluxes in isolated hepatocytes. J Biol Chem 260:13613-13618

16. Orcel P, Denne MA, De Vernejoul MC (1991) Cyclosporin A in vitro decreases bone resorption, osteoclast formation, and the fusion of cells of the monocyte-macrophage lineage. Endocrinology $128: 1638-1646$

17. Vaes G (1988) Cellular biology and biochemical mechanisms of bone resorption. Clin Orthop Rel Res 231:239-271

18. Majeska RJ, Rodan SB, Rodan GA (1980) Parathyroid hormone- responsive clonal cell lines from rat osteosarcoma. Endocrinology 107:1494-1503

19. Hansen MB, Nielsen SE, Berg K (1989) Re-examination and further development of a precise and rapid dye method for measuring cell growth/cell kill. J Immunol Methods 119:203-210

20. Wrana JL, Maeno M, Hawrylshyn B, Yao KL, Domenicucci C, Sodek J (1988) Differential effects of transforming growth factor-beta on the synthesis of extracellular matrix proteins by normal fetal rat calvarial bone cell populations. J Cell Biol 106: 915-924

21. McCauley LK, Rosol TJ, Merryman JI, Capen CC (1992) Parathyroid hormone-related protein binding to human T-cell lymphotropic virus type-I-infected lymphocytes. Endocrinology 130:300-306

22. Nissenson RA, Diep D, Strewler GJ (1988) Synthetic peptides comprising the amino-terminal sequence of a parathyroid hormone-like protein from human malignancies. J Biol Chem 263: 12866-12871

23. Stewart PJ, Stern PH (1991) Interaction of cyclosporine A and calcitonin on bone resorption in vitro. Horm Metab Res 21:194 197

24. The Canadian Multicentre Transplant Study Group (1983) A randomized clinical trial of cyclosporine in cadaveric renal transplantation. N Engl J Med 309:809-815

25. Larsson EL (1980) Cyclosporin A and dexamethasone suppress $T$ cell responses by selectively acting at distinct sites of the triggering process. J Immunol 124:2828-2833

26. Schweighoffer T, Schweighoffer E, Apati A, Antoni F, Molnar G. Lapis K, Banfalvi G (1991) Cytometric analysis of DNA replication inhibited by emetine and cyclosporin A. Histochemistry $96: 93-97$

27. Wong $G$ (1990) Isolation and behavior of isolated bone-forming cells. In: Hall BK (ed) The osteoblast and osteocyte. The Telford Press, Caldwell, NJ, pp 171-192

28. Majeska RJ, Rodan GA (1982) The effect of $1,25(\mathrm{OH})_{2} \mathrm{D}_{3}$ on alkaline phosphatase in osteoblastic osteosarcoma cells. J Biol Chem 257:3362-3365

29. Skjodt H, Crawford A, Elford PR, Ihrie EE, Wood DD, Russell GG (1985) Cyclosporin A modulates interleukin-1 activity on bone in vitro. Br J Rheumatol 24:165-169

30. Somerman MJ, Prince CW, Butler WT, Foster RA, Moehring JM, Sauk JJ (1989) Cell attachment activity of the 44 kilodalton bone phosphoprotein is not restricted to bone cells. Matrix 9: $49-54$

31. Somerman MJ, Schiffman E, Reddi AH, Termine J (1982) Reg ulation of the attachment and migration of bone cells in vitro. $J$ Periodont Res 17:527-531

32. Simmons DJ, Grynpas MD (1990) Mechanisms of bone formation in vivo. In: Hall BK (ed) The osteoblast and osteocyte. The Telford Press, Caldwell, NJ, pp 193-302

33. McSheehy PMJ, Chambers TJ (1986) Osteoblast-like cells in the presence of parathyroid hormone release soluble factor that stimulates osteoclastic bone resorption. Endocrinology 119: 1654-1659

34. Schlosberg M, Movsowitz C, Epstein S, Ismail F, Fallon MD, Thomas S (1989) The effect of cyclosporin A administration and its withdrawal on bone mineral metabolism in the rat. Endocrinology 124:2179-2184 